\title{
NK-cell enteropathy
}

INSERM

\section{Source}

INSERM. (1999). Orphanet: an online rare disease and orphan drug data base. NK-cell enteropathy. ORPHA:263665

Natural killer (NK)-cell enteropathy is a benign NK-cell lymphoproliferative disease characterized by minor abdominal symptoms (abdominal pain, diverticulosis, constipation and reflux) due to NK cell-derived lesions in the mucosal layer of the gastrointestinal tract and often mistaken for NK or T-cell lymphoma (see these terms). 